\title{
EFFECT OF SOME PLANT DENSITIES PATTERNS AND NITROGEN FERTILIZER RATES ON COTTON YIELD, ITS COMPONENTS AND FIBRE PROPERTIES FOR HYBRID COTTON 10229 X GIZA 86 UNDER EARLY AND LATE SOWING
}

\author{
Amal S. A. Abd El-Aal
}

Cotton Res. Inst., ARC, Giza, Egypt

\section{ABSTRACT}

Four field experiments were conducted at Sakha Agriculture Research Station, Kafr El-Sheikh Governorate during 2011 and 2012 seasons. Early and late sowing experiemnts were carried out in the first season and repeated in the second season. These experiments were conducted to study the response of hybrid cotton 10229 x Giza 86 to agricultural systems, i.e., 43077 plants/fed. $(65 \mathrm{~cm}$ ridge width and $30 \mathrm{~cm}$ hill spacing on one side), 36923 plants/fed. (65 cm ridge width and $35 \mathrm{~cm}$ hill spacing on one side), 48000 plants/fed. $-(100 \mathrm{~cm}$ ridge width and $35 \mathrm{~cm}$ hill spacing on two sides) and 42000 plants/fed. (100 cm ridge width and $40 \mathrm{~cm}$ hill spacing on two sides) and nitrogen levels of 45,60 and $75 \mathrm{~kg} / \mathrm{fed}$. Plants were thinned to two plants per hill after the formation of the second true leaf. Two of these experiments were carried out for the early sowing (15 April), but the other two experiments for the late sowing (15 May). The treatments carried out in the early planting also applied in the late sowing. The results can be summarized as follow:

1. Increasing plant population density significantly increased final plant height, number of monopodia, number of sympodia per plant, number of main stem internodes/plant, nodal position of first sympodium, shedding percentage, number of open bolls and unopen bolls/plant, boll weight and seed cotton yield (kentar/fed.) in the two seasons. However, earliness percentage and percentage of plant losses/fed. significantly decreased by increasing plant density.

2. There were significant differences among the three nitrogen levels, in all growth, earliness characters and yield and its components. Application of $75 \mathrm{~kg} \mathrm{~N} / \mathrm{fad}$. produced the highest values of plant height, number of monopodia and sympodia/plant, number of main stem internodes/plant, nodal position of the first sympodium, number of open and unopen bolls, boll weight and seed cotton yield (kentar/fed.), while the lowest nitrogen level (45 kg N/fed.) produced the lowest values of earliness $\%$, shedding $\%$ and stand losses $\%$ at harvest. Seed index, lint percentage and fiber properties insignificantly affected by all treatments. The interaction between agricultural systems and nitrogen levels attained insignificant effect on all traits.

3. The results showed that late sowing took the same direction as early planting and were higher values for the number of bolls, boll weight, yield and its components.

In general, it can be stated that early sowing (15 April) of hybrid cotton 10229 x Giza 86 with $75 \mathrm{~kg} \mathrm{~N} / \mathrm{fed}$. and higher density 48000 plants/fed $(100 \mathrm{~cm}$ ridge width and $35 \mathrm{~cm}$ hill spacing on two sides) induced higher seed cotton yield.

\section{INTRODUCTION}

It is well known that vegetative characters, yield and its components and earliness measurements of cotton are governed by many environmental factors such as planting date, which ranks high among the important factors affecting the cotton production, as well as light intensity which resulted from varying plant distributions. Whatever, the exact interactions which result in 
high vegetative/reproductive ratio, the implication of the hypothesis is that the importance of setting the early bolls for outweighs their direct contribution to yield. In this concern, plant population density and nutritional status play an important item in consolidating this ratio. From the study of Low and McMahon (1973), higher plant densities reduced number of nodes to the first fruiting branch and increased earliness. Guinn et al. (1981) revealed that low populations (5200 plants/ha) produced more retained bolls and higher yields than high one (94000 plants/ha). The low population caused no appreciable delay in setting the crop, while the high one increased boll abscission rate and boll infestation. El-Hattab et al. (1976) and Eweida et al. (1981) found that boll weight and number of open bolls increased by decreasing plant population. Using $76 \mathrm{~cm}$ inter row spacing at 5,10 and 15 plants $/ \mathrm{m}^{2}$, Kerby et al. (1990) reported that increasing plant density increased final plant height and delayed maturity. Earliness associated with a lower node number of the first fruiting branch, more rapid production of early main-stem nodes and increased retention of early fruiting forms in lower density. Makram et al. (1994) reported that the intermediate hill spacing of $25 \mathrm{~cm}$ increased fruiting branches/plant, yield components and yield/fed. Final plant height and earliness percentage were increased in favour of closer spacing. Wider spacing increased monopodia, sympodia, open bolls and boll weight. Hosny et al. (1995) using different intra and inter-row spacing, revealed that maturity was faster with high plant density and narrow row spacing. Number of open bolls/plant was highest with low plant density and narrow row spacing. High seed cotton yields were obtained with 35000-70000 plants/fed. and $40 \mathrm{~cm}$ row spacing. Many investigators studied the effect of plant distributions and sowing date; Shalaby and Saker (1980) and Saker (1983) found that the yield, boll weight, lint percentage and seed index were increased by early planting. El-Gamal (1983) mentioned that early sowing delayed both first open boll and node location of the first sympodium but increased boll weight. El-Sayed (2005) found that early sowing (25 March) significantly increased number of internodes and sympodia on the main stem, number of open bolls per plant, boll weight, number of the first flower appearance, days to the first cracking boll, earliness percentage and seed cotton yield per plant and per feddan, while the reverse trend was noticed with plant height, internode length, numbers of monopodial branches and first sympodium position. $\mathrm{He}$ added that position of first sympodium, days to first flower appearance and cracking boll and earliness percentage were increased when cotton plants were sown early in the season. Also, the early sowing date $\left(25^{\text {th }}\right.$ March) produced the highest value of open bolls, boll weight, seed cotton yield/plant and feddan, while number of unopen bolls/plant, seed index and lint percentage were not significantly affected by sowing date. Hill spacing and nitrogen levels are two of the cultural practices that exert marked effects on the yield and yield components of cotton. The oldest and consecutive traits in this concept were the achievement of the proper plant density and nitrogen level which can maximize cotton productivity specially in the new varieties.

As nitrogen is an essential nutrients for cotton that affects plant growth, fruiting and yield. Makram et al. (1992) found that increasing nitrogen rates increased number of open bolls. El-Shinnawy et al. (1984) showed that plant 
height, number of fruiting branches, seed cotton yield, boll weight and number of bolls per plant were increased by increasing nitrogen level previous studies indicated that increasing nitrogen rate increased plant height (El-Shahawy et al., 1994) number of vegetative branches (Abd El-Malik, 1976); number of fruiting branches (El-Kadi, 1986 and El-Bana et al., 1988), number of open bolls (Lashin et al., 1979 and Ali, 1990), boll weight (El-Bana et al., 1988) and seed cotton yield (Ali, 1990 and Makram et al., 1994), but it decreased earliness percentage (Kater Hake et al., 1991). El-Sayed and El-Menshawi (2005) found that increasing nitrogen levels up to $80 \mathrm{~kg} / \mathrm{fed}$. increased final plant height, number of monopodia per plant, number of main stem internodes, number of sympodia per plant, position of first sympodium, days to first cracking boll, number of open and unopen bolls per plant, boll weight, seed cotton yield per plant and feddan, but had no significant effect on seed index, lint percentage and fibre properties.

Therefore, this investigation was carried out to study the effect of some plant densities and nitrogen fertilizer rates on cotton yield and its components for hybrid cotton 10229 x Giza 86 under the early and late sowing.

\section{MATERIALS AND METHODS}

Four experiments were carried out at Sakha Agricultural Research Station during 2011 and 2012 using the hybrid cotton 10229 x Giza 86 which characterized by high yield and its components. These experiments were divided into two series, each contained two experiments. The first series to study the effect of early sowing (15 April) on some plant densities and nitrogen levels but the second series to study the effect of late sowing (15 May) for the same treatments.

Split plot design was used for all experiments. The preceding crop was rice in the two seasons. Plants were thinned to two plants per hill after the formation of the second true leaf. Nitrogen fertilizer was added in bands and divided in two equal portions, the first one was applied after thinning just before the second irrigation and the second part before the third irrigation. Other cultural practices were done as recommended in cotton production that is involved a basic dose of $150 \mathrm{~kg}$ calcium super phosphate $\left(15.5 \% \quad \mathrm{P}_{2} \mathrm{O}_{5}\right)$ during land preparation besides $50 \mathrm{~kg}$ potassium sulphate $\left(48 \% \mathrm{~K}_{2} \mathrm{O}\right)$ per feddan before the fourth irrigation for all plots. Soil samples were taken in the two seasons before planting cotton to estimate the soil characters using the standard methods as described by Chapman and Parker (1981). The results of soil chemical analysis are presented in Table (1).

Table (1): Chemical analysis of soil samples which were taken at the depth of 0-30 cm from the surface in 2011 and 2012 seasons.

\begin{tabular}{|l|c|c|}
\hline Soil characteristics & $\mathbf{2 0 1 1}$ & $\mathbf{2 0 1 2}$ \\
\hline Texture & Clay & Clay \\
\% Organic matter & 1.80 & 1.90 \\
ECe (Soil paste $\left.25^{\circ} \mathrm{C}\right)$ & 4.10 & 3.74 \\
pH & 8.92 & 8.60 \\
Available N (K-sulphate ext.) & 12.50 & 13.10 \\
Available P (Olsen ext.) & $20.1 \mathrm{ppm}$ & $24 \mathrm{ppm}$ \\
Available K (Amm-acetate ext.) & $210 \mathrm{ppm}$ & $214 \mathrm{ppm}$ \\
\hline
\end{tabular}

Soil and Water Res. Inst., Agric. Res. Center, Giza, Egypt. 
Table (2):Monthly air temperature $\left({ }^{\circ} \mathrm{C}\right)$ and relative humidity during 2011 and 2012 seasons.

\begin{tabular}{|c|c|c|c|c|c|c|c|c|}
\hline \multirow{3}{*}{ Months } & \multicolumn{4}{|c|}{2011} & \multicolumn{4}{|c|}{2012} \\
\hline & \multicolumn{2}{|c|}{ Air Temp..$^{\circ} \mathrm{C}$} & \multicolumn{2}{|c|}{ RH\% } & \multicolumn{2}{|c|}{ Air Temp. ${ }^{\circ} \mathbf{C}$} & \multicolumn{2}{|c|}{$\mathbf{R H} \%$} \\
\hline & Max. & Min. & Max. & Min. & Max. & Min. & Max. & Min. \\
\hline March & 21.8 & 6.8 & 86.3 & 49.5 & 22.2 & 7.7 & 88.2 & 48.2 \\
\hline April & 26.5 & 10.0 & 85.0 & 47.7 & 27.1 & 11.1 & 88.0 & 46.6 \\
\hline May & 29.0 & 13.0 & 76.7 & 38.0 & 28.7 & 12.8 & 70.1 & 39.0 \\
\hline June & 32.0 & 17.2 & 82.5 & 46.5 & 33.7 & 18.3 & 82.3 & 47.0 \\
\hline July & 33.0 & 19.4 & 79.5 & 49.2 & 34.0 & 19.3 & 78.9 & 48.0 \\
\hline August & 32.5 & 19.2 & 84.0 & 52.0 & 34.2 & 18.9 & 83.9 & 53.1 \\
\hline September & 33.2 & 17.7 & 88.0 & 49.6 & 34.9 & 17.3 & 86.1 & 46.7 \\
\hline October & 28.0 & 14.0 & 82.0 & 48.0 & 29.1 & 14.8 & 83.2 & 47.9 \\
\hline
\end{tabular}

Data presented above were daily taken and calculated as an average per month (cited after Sakha Weather station)

Experiments of the first series (Early sowing):

Two field experiments were performed to investigate the effect of plant densities, nitrogen levels and their interaction on growth characters; earliness parameters and seed cotton yield and its components of hybrid cotton $10229 \mathrm{x}$ Giza 86 under the early sowing (15 April) in the two seasons. Split plot design with four replications was used. The main plots were assigned for plant densities, i.e., ridges, $65 \mathrm{~cm}$ width with $30 \mathrm{~cm}$ hill spacing on one side (43077 plants/fed., ridges $65 \mathrm{~cm}$ width with $35 \mathrm{~cm}$ hill spacing on one side (36923 plant/fed.); ridges $100 \mathrm{~cm}$ width with $35 \mathrm{~cm}$ hill spacing on two sides (48000 plants/fed.) and ridges $100 \mathrm{~cm}$ width with $40 \mathrm{~cm}$ hill spacing on two sides (42000 plants/fed.). In all cases, two plants were left. The sub plots were devoted for nitrogen levels of 45,60 and $75 \mathrm{~kg} / \mathrm{fed}$. Plot size was $19.5 \mathrm{~m}^{2}$ (3.90 $\mathrm{m}$ width $\times 5 \mathrm{~m}$ length).

\section{Experiments of the second series (late sowing):}

Two experiments were conducted to study the effect of plant densities, nitrogen level and their interaction on growth characters; earliness parameter and seed cotton yield and its components of hybrid cotton $10229 \mathrm{x}$ Giza 86 under late sowing (15 May) in the two seasons. The same treatments that have been implemented in the first series carried out in the second series recorded data.

Ten guarded plants were chosen at harvest by random from each plot to determine the following characters.

\section{A. Plant growth:}

Final plant height in $\mathrm{cm}$, number of monopodia, number of main stem internodes and number of sympodia per plant.

\section{B. Earliness measurements:}

Position of the first sympodium, earliness percentage and shedding percentage. 
Earliness percentage $=$

Seed cotton of first picking

Seed cotton of first picking + seed coton of second picking $x 100$

\section{Yield and yield components:}

Number of open bolls per plant, number of un open bolls per plant, boll weight in $\mathrm{g}$, seed cotton yield (kentar/fed.), seed index (g/100 seeds), lint percentage and plant losses at harvest \%.

\section{Fibre properties:}

The following properties were determined at the Cotton Research Institute, Giza, Egypt.

1. Fibre fineness was tested by micronaire.

2. Fibre strength was tested by Pressely apparatus at zero guage length.

3. Fibre length: Fibre $2.5 \%$ span length measured on a digital fibrograph according to Standard Method of testing fibre length.

4. Fibre elongation \%: measured by the Stelometer.

Analysis of variance was performed on all data according to Snedecor and Cochran (1981), and treatment averages were compared at 0.05 level of probability using LSD.

\section{RESULTS AND DISCUSSION}

The experiments of the first series:

Effect of early sowing (15 April) on some plant densities and nitrogen levels:

\section{A. Growth habits:}

Data presented in Table (3) showed that final plant height, number of monopodia, number of sympodia and number of main stem internodes per plant were high significantly affected by plant density in the two seasons. Increasing plant density increased all this growth traits. This increase might be due to the increase in main stem nodes and it could be explained as a result of excessive shade which increase gibberellin content in plant tissues (Wareing and Philips, 1970 and Makram et al., 1994). It is well noticeable that ridges of two planted sides had more plant population than ridges of single planted side which increases within plants competition with continued development especially at boll load stage. So, the availability of water and nutrients to individual plants decreased and that reflects it drastic effect on final plant size. This conclusion appear to agree with those of Ziadah (1983), Yasseen (1986) and El-Shahawy et al. (1993).

As for $\mathrm{N}$ level, final plant height, number of monopodia, number of sympodia and number of main stem internodes per plant increased significantly as nitrogen level increased from 40 to $75 \mathrm{~kg} / \mathrm{fed}$. The previous trend might be due to soil reduction in organic matter and available nitrogen as presented in Table 1. Similar results were reported by Makram et al. (1994). The above increment in some growth characters may be due to the importance of nitrogen for many basic physiological processes in cotton plants such as photosynthetic rate and accumulation of carbohydrates. Similar results were obtained by ElGahel et al. (1989) and El-Sayed and El-Menshawi (2001). 


\section{B. Earliness parameters:}

Combined data in Table (4) clear that plant density positively affected shedding, nodal position of the first sympodium and earliness percentage. It is obvious that dense stands significantly raised nodal position of the first sympodium and increased shedding percentage, while decreased earliness percentage. As a result, more time is required to set the crop and consequently maturity is delayed. Delay in maturation of dense stands might be due to that in crowded planting, boll retention on the lowest sympodia may be reduced from excessive shading higher subjection to insects or both. The end results was unthrifty plants that matured late. These results agree with those obtained by Imam (1984) for first sympodial position, Abd El-Kader (1980) for earliness percentage and El-Shahawy et al. (1993) for shedding percentage.

On the other hand, the results indicate that delay in maturation due to both higher values of first sympodial position and earliness percentage were markedly detected when cotton plants received maximum nitrogen $(75 \mathrm{~kg} / \mathrm{fed}$.). It is noticed that increasing nitrogen level from 40 up to $75 \mathrm{~kg} / \mathrm{fed}$. significantly raised the location of the first sympodium, decreased earliness percentage and shedding percentage. These results could be explained on the basis that excess application of nitrogen fertilizer caused excessive vegetative growth which in turn increased the shading of fruiting bodies on lower fruiting branches as a result of the shading due to excessive vegetative growth and consequently resulted in delayed maturity (Ali and El-Sayed, 2001). Similar findings were obtained by Kater Hake et al. (1991) and Abdel-Aal (1997)

\section{Yield and its components:}

Combined data presented in Table (5) clear the effect of plant densities, nitrogen levels and their interaction on seed cotton yield and its components of hybrid cotton 10229 x Giza 86 under the early sowing (15 April). It is clear that plant densities had significant effects on number of open bolls/plant, number of unopen bolls/plant, boll weight and seed cotton yield/feddan. It is realized that cotton plants grown on ridges $100 \mathrm{~cm}$ width 35 or $40 \mathrm{~cm}$ hill spacing (48000 or 42000 plant/feddan) resulted in higher number of open bolls/plant, boll weight and seed cotton yield (kentar/fed.) and number of unopen bolls/plant at the end of season compared with those sown on ridges $65 \mathrm{~cm}$ at one side and 30 or 35 hills spacing (43077 or 36923 plant/fed., respectively).

This result may be attributed to the better distribution of cotton plants in the field that may be enable the plants to make the best use of solar energy and this would enhance vegetative growth and dry matter accumulation which in turn increase plant capacity for building up metabolites. These results were in agreement with those obtained by El-Shinnawy and Hosney (1984) and ElGahel (1991). Also, Abd El-Malik (1999) found the same results when seeds of cotton were sown on square contour lines.

Seed cotton yield and most yield components studied herein except percentage of plant losses at harvest were significantly differed as $\mathrm{N}$-levels diverged. In this connection, cotton plants received $\mathrm{N}$ rate $(75 \mathrm{~kg} / \mathrm{fed}$.) produced higher open boll number/plant, number of unopen boll/plant, boll weight and seed cotton yield (kentar/fed.). On the other hand, percentage of plant losses at harvest did not react with $\mathrm{N}$ application. Seed cotton yield and most of its components responded positively to the additional amount of 
nitrogen was the resultant expression for the reduction of the soil content of organic matter and available $\mathrm{N}$ (Table 1).

These results indicate that promising hybrid cotton $10229 \times$ Giza 86 has high response to nitrogen fertilization. These results might be explained on the basis that increasing nitrogen levels up to $75 \mathrm{~kg} / \mathrm{fed}$. gave cotton plants with its requirements from nitrogen which provide the small formed bolls with its requirements, resulting in more setting of bolls and decrease the shedding of fruiting organs per plant which reflected on seed cotton yield per plant and feddan. These results are in agreement with those obtained by El-Shahawy et al. (1994) and Abd El-Aal (1997).

Results in Table (5) indicate that seed index and lint percentage in both seasons were not significantly affected by plant densities and nitrogen levels. The same trend was obtained by El-Sayed and El-Menshawi (2005).

The results cleared that late (15 May) sowing had significantly increase plant height, number of main stem internodes per plant, number of monopodia and number of sympodia per plant. The reverse was true for early sowing. These results may be due to that sowing early (15 April) fit cotton plants to full season in order to obtain complete heat unit requirements (Table 2) for good growth (Young et al., 1980). Similar results were obtained by Makram et al. (1994) and Abd El-All (1997).

Data in Table (6) indicate that plant densities, nitrogen levels and their interaction did not significantly affect fibre properties for this hybrid cotton 10229 x Giza 86 under early sowing (15 April). This may be attributed to the high genetic stability of these characters. Similar results were obtained by El-Sayed et al. (2006).

The experiments of the second series:

Effect of late sowing (15 May) on some plant densities and nitrogen levels:

Tables 7, 8 and 9 show the effect of late plant densities on growth characters, earliness measurements and seed cotton yield and its components. Combined data clear that the impact of plant densities and nitrogen fertilization on the latest plant densities take the same direction for early sowing and the previously mentioned. Data presented in Table (7) show that increasing plant density increased all growth characters. It is obvious that the late sowing (15 May) produced the tallest plants, number of internodes and vegetative branches. This trend of results may be obtained because with late sowing date more of the growth occur under higher temperature (Table 2) and this apparently accelerated stem elongation with lower number of both stem nodes and sympodia per plant. Such findings were obtained by Makram et al. (1994) and Reddy et al. (1992).

The data presented in Table (7) cleared that final plant height, number of monopodia and sympodia per plant and number of main stem internodes per plant were significantly increased in favour of nitrogen increase up to 75 $\mathrm{kg} / \mathrm{feddan}$. The observed results obtained may be due to higher temperature led to encourage plants to form excessive vegetative growth with few fruiting forms through short plant life (Ali and Elsayed, 2001).

Combined data presented in Table (8) show that plant density of late sowing positively affected shedding and earliness percentages. These results 
may be ascribed on the basis that excessive vegetative growth of low plant density normally resulted in higher photosynthesis rate which in turn caused more boll setting with lower shedding and late boll maturation. On the other hand, decreasing nitrogen led to increase in shedding and earliness percentages. These results may be to more shedding may be attributed to inadequate feeding nutrients caused by low nitrogen level.

These results are in agreement with those obtained by Makram et al. (1982) and McConnell et al.(1993).

Combined data presented in Table (9) showed that seed cotton yield and its components of hybrid cotton 10229 x Giza 86 under the late sowing (15 May) significantly affected by plant density in both seasons. Using higher plant density (48000) (ridges $100 \mathrm{~cm}$ width $35 \mathrm{~cm}$ hill spacing in 2 sides) gave higher number of open bolls and unopen bolls per plant, boll weight and seed cotton yield (kentar/fed.). These results can be attributed to higher and suitable number of plants at harvest which expressed higher seed cotton yield per feddan. This result may be attributed to the better distribution of cotton plants in the field which may be enable the plants to make the best use of solar energy and this would enhance vegetative growth, which in turn increase plant capacity for building up metabolites. These results were in agreement with those obtained by El-Shinnawy and Hosney (1984), El-Gahel (1991) and Abd El-Malik (1999). Increasing nitrogen level significantly and gradually increased number of open and unopen bolls per plant, boll weight and seed cotton yield per feddan in both seasons. This result might due to that deficiency of feeding nutrients in the soil (Table 1) magnified the effect of additional doses of nitrogen. These results are in harmony with those obtained by Makram et al. (1982) and El-Gahel (1987).

Lint percentage, seed index and fibre properties were not significantly affected by both factors under study and the differences can be neglected. This may be attributed to the high genetic stability of these characters. The same trend was obtained by El-Sayed et al. (2006). The interaction between plant densities and nitrogen levels had no significant effect for all traits under study in both seasons.

\section{CONCLUSION}

Generally, from the two previous experiments, it could be concluded that for the promising hybrid cotton $10229 \times$ Giza 86, the optimum plant densities (Ridges $100 \mathrm{~cm}$ width $35 \mathrm{~cm}$ hill spacing two sides, 48000 plants/fed.) and highest nitrogen level $75 \mathrm{~kg} \mathrm{~N} / \mathrm{fed}$. produced the highest yield and its components under the early sowing.

\section{REFERENCES}

Abd El-Aal, S.A.I. (1997). Effect of ridging rates in combination with hill spacing and nitrogen levels on growth, earliness, yield and yield components of Giza 86 cotton cultivar. J. Agric. Res. Tanta Univ., 23(1): 9-17.

Abd El-Kader, A.E. (1980). Effect of planting dates and watering regime on yield and quality of cotton. M.Sc. Thesis, Fac. Agric., Assiut Univ., Egypt. 
Abd El-Malik, R.R. (1976). Effect of some cultural practices on cotton (effect of plant population and $\mathrm{N}$-fertilization on some characteristics of two Egyptian cotton varieties, Giza 45 and Giza 68). M.Sc. Thesis, Fac. Agric., Alex. Univ.

Abd El-Malik, R.R. (1999). Behaviour of Giza 89 cotton cultivar under different plant densities. J. Agric. Sci. Mansoura Univ., 24(2): 399411.

Ali, S.E.A. (1990). Efficiency of experimental designs of fertilization and irrigation in Egyptian cotton. Ph.D. Thesis, Fac. Agric., Al-Azhar Univ., Egypt.

Ali, S.E.A. and El-Sayed (2001). Effect of sowing date and nitrogen levels on growth, earliness and yield of Egyptian cotton Giza 88. Agric. Res. Rev., 79(1): 221-232.

Chapman, H.D. and F.P. Parker (1981). Methods of analysis of soil, plants and water. Univ. California, August, 1981, Second Printing.

El-Bana, M.H.; S.M. El-Gahel and A.M. El-Shinnawy (1988). Effect of nitrogen levels and topping dates on yield of late sown Giza 81 cotton. Proc. $3^{\text {rd }}$ Egyptian Conf. Agron., Kafr El-Sheikh, 5-7 Sept., 11: 65-72.

El-Gahel, S.M.f. (1987). Studies on overlapping between onion and cotton. Ph.D. Thesis, Fac. Agric., Tanta Univ., Egypt.

El-Gahel, S.M.F. (1991). Effect of some planting patterns on growth and yield of cotton. J. Agric. Res.. Tanta Univ., 17(3):1991.

El-Gahel, S.M.F.; M.M. El-Razaz and A.M. El-Shinnawy (1989). Effect of dates and levels of $\mathrm{N}$ application at late sowing of cotton. Menoufia, J. Agric. Res., 14(2): 875-884.

El-Gamal, H.E.A. (1983). Study on earliness components in cotton and their effects on yield and quality. M.Sc. Thesis, Fac. Agric., Al-Azhar Univ.

El-Hattab, H.A.; M.H. El-Shaer; A.A. Abo Zahab and A.M. Samra (1976). Response of two Egyptian cotton cultivars to plant population density. Agric. Res. Rev., Egypt, 54(9): 1-14.

El-Kadi, M.B.M. (1986). Effect of macro- and micronutrients on yield, yield components and quality of cotton plants. Ph.D. Thesis, Fac. Agric., Ain Shams Univ., Egypt.

El-Sayed, E.A. (2005). Effect of sowing and thinning dates on growth and yield of cotton. J. Agric. Sci. Mansoura Univ., 30(1): 41-48.

El-Sayed, E.A. and M. El-Menshawi (2001). Response of late sowing cotton cultivar (Giza 88) to times of potassium application under different levels of nitrogen. J. Agric. Sci. Mansoura Univ., 26(9): 5177-5188.

El-Sayed, E.A. and M. El-Menshawi (2005). Response of the promising hybrid cotton Giza 89 × 86 to hill spacing and nitrogen fertilizer level. J. Agric. Res., Tanta Univ., 31(3): 436-456.

El-Sayed, E.A.; M.E. El-Menshawi and R.R. Abd El-Malik (2006). Effect of different fertilizer doses (NPK) on the yield components and some chemical constituents of the hybrid, cotton Giza 89 x 86. Egypt. J. of Appl. Sci., 21(4A).

El-Shahawy, M.I.; Abd El-Malik, R.R. and Sayeda, S. El-Helow (1993). Response of the new cotton variety Giza 84 to different hill spacing 
and nitrogen levels . Annals of Agric. Sci., Moshtohor, 31(3): 13351345.

El-Shahawy, M.I.; S.M. El-Gahel and E.A. Makram (1994). Effect of planting dates, hill spacing and nitrogen levels on Giza 76 cotton cultivar. J. Agric. Res. Tanta Univ., 20(2): 63-64.

El-Shinnawy, A.M. and A.A.A. Hosney (1984). Effect of row width and hill spacing on yield and yield components of Giza 80 cotton variety. Agric. Res. Rev., 62(2): 79-85.

El-Shinnawy, A.M.; F.M. Ghaly and A.A.A. Hosny (1984). Effect of row width and hill spacing on yield and yield components of Giza 80 cotton variety. Agric. Res. Rev., 62(6): 79-89.

Eweida, M.H.; M.A. Rizk; E.A. Makram and A.M. Taleb (1981). Effect of plant density on growth, yield and some fiber properties of Giza 75 cotton variety. Fac. Agric., Ain Shams Univ., Res. Bull. 1678, Cairo, Egypt.

Guinn, G.; J.R. Mauney and K.E. Fry (1981). Irrigation scheduling and plant population effects on growth, bloom rates, boll abscission, and yield of cotton. Agron. J. Vol. 73, May-June 529-534.

Hosny, A.A.; A.M. Eid and K.A. Ziadah (1995). Prediction of optimum population density and row spacing of cotton in different regions of Egypt. Annals of Agric. Sci., Moshtohor, 33(1): 1-20.

Imam, G.M.I. (1984). A study of some factors affecting thinning rates in Egyptian cotton. M.Sc. Thesis, Fac. of Agric., Ain Shams Univ..

Kater, Hake, Ken Cassman and Wayne Ebelhar (1991). Cotton nutrition-N, P and $\mathrm{K}$ physiology today, newsletter of the cotton physiology education program. National Cotton Council of America, 2(3).

Kerby, T.A.; K.G. Cassman and M. Keeley (1990). Genotypes and plant densities for narrow row cotton systems. 1-Height nodes, earliness and location of yield. Crop Sci. 30: 644-649.

Lashin, M.H.; L.Kh. Mohamed; M.S. El-Haroun and I.A.I. Helal (1979). Effect of some agricultural practices on the growth and yield of some Egyptian cotton cultivars. Menufiya J. Agric. Res.

Low, A. and J.P. McMahon (1973). Development of narrow row, high density cotton in Australia. 1. Effect on yield. 2-Effect on fibre quality. 3Effect on mechanization and cultural practices. Cotton Growing Review, 50(2): 130-149.

Makram, E.A.; A.A. Sallam and A.A. El-Gohary (1982). Effect of hill spacing under different nitrogen rates on yield components, yield and some fiber properties of Egyptian cotton cultivar, Giza 75. Res. Bull., Fac. Agric., Ain Shams Univ., 37(2): 1731-1750.

Makram, E.A.; M.I. El-Shahawy; S.F. El-Gahel and R.R. Abdel Malik (1994). Effect of hill spacing, soil fertilization and its interaction on growth, yield and earliness in Egyptian cotton cultivars, 1-Giza 70. J. Agric. Sci. Mansoura Univ., 1: 13.

McConnell, J.C.; W.H. Baker; D.M. Miller; B.S. Frizzell and J.J. Varvil (1993). Nitrogen fertilization of cotton cultivars of different maturity. Agron. J. 85(6): 1151-1156. 
Reddy, K.R.; V.R. Reddy and H.F. Hodges (1992). Temperature effects on early season cotton growth and development. Agron. J. 84(2): 229243.

Saker, I.A.E. (1983). Physiological response of some Egyptian cotton varieties to plant population. Ph.D. Thesis, Fac. Agric., Ain Shams Univ.

Shalaby, Y.Y. and L.A.E. Saker (1980). A study of some flowering and bolling characters as affected by some cultural operations. $1^{\text {st }}$ Cotton. Conf. Agric. Res. Cent. Egypt, 12-15 Oct. 1980.

Snedecor, G.W. and W.G. Cochran (1981). Statistical analysis methods seventh edition. lowa State Univ., Ames, lowa, USA.

Wareing, R.E. and I.D.G. Philips (1970). The control of growth and differentiation in plants. Program Press Ltd., Headington, Hill Gall, Oxford, USA, $303 \mathrm{pp}$.

Yasseen, A.I.H. (1986). The relationship between treatments for some Egyptian and American cotton varieties. Ph.D. Thesis, Fac. of Agric. Ain Shams Univ.

Young, E.F.; R.M. Taylor and H.D. Peterse (1980). Days degree unit and time in relation to vegetative development and three cultivars of cotton. Crop Sci., 20: 320-375.

Ziadah, K.A.K. (1983). Effect of plant population and fertilization rates on growth and yield for some Egyptian cotton cultivars. Ph.D. Thesis, Fac. of Agric., Ain Shams Univ.

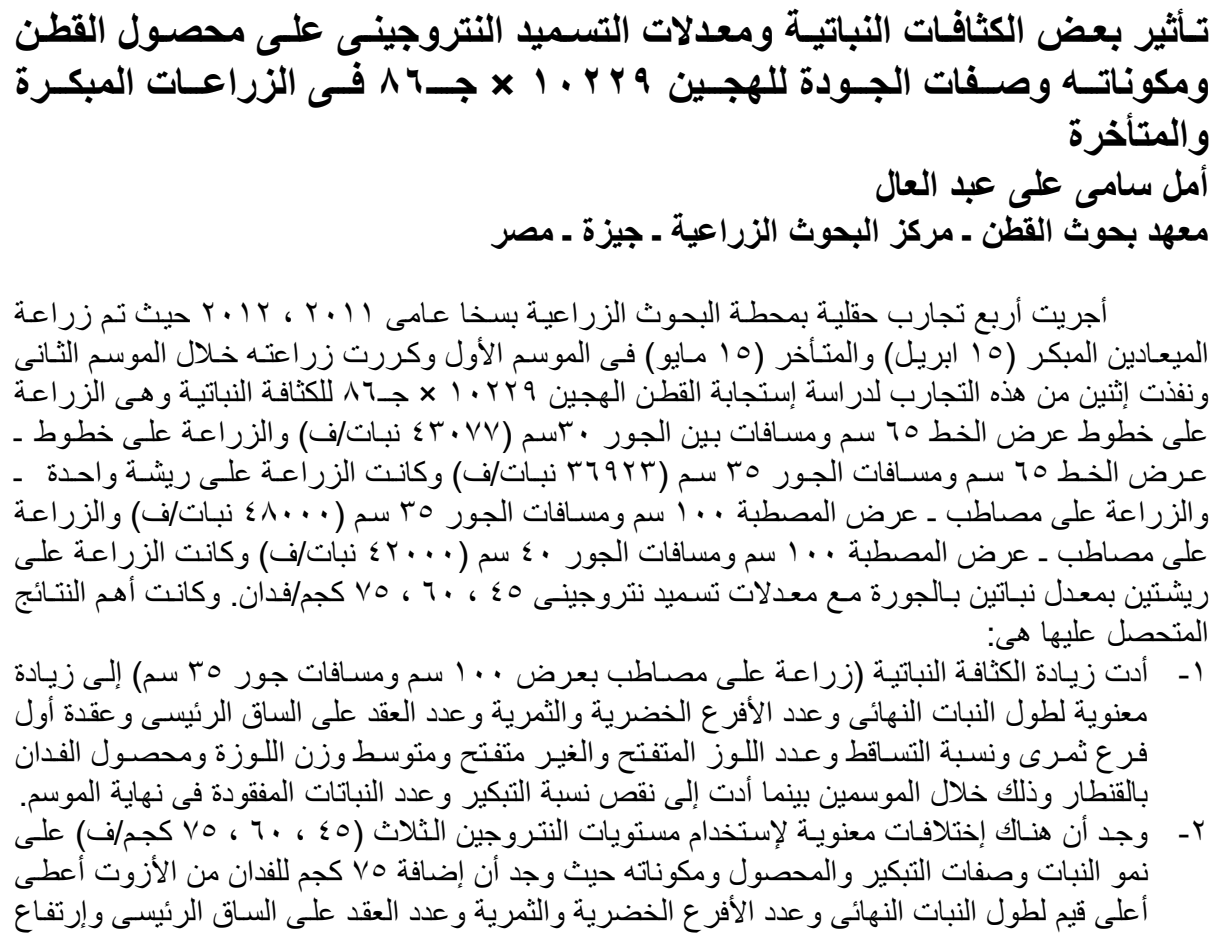




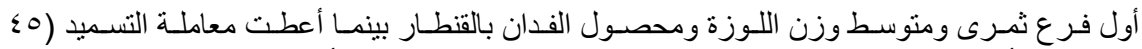

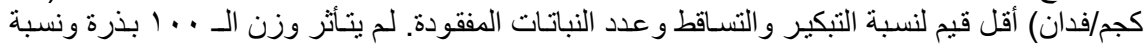
الثعر والصفات التكنولوجية للتيلة معنويا خلال الموسمين.

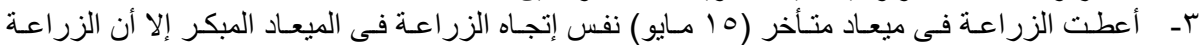

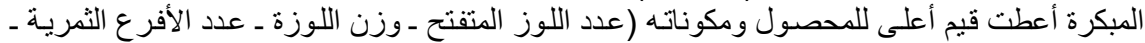
و إنخفاض موقع أول فرع ثمرىى).

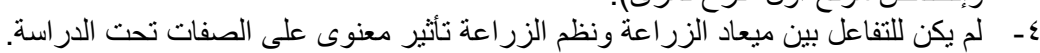

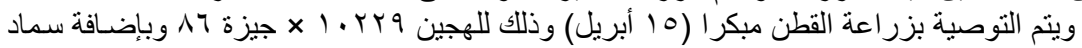

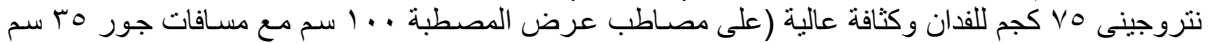
و الزراعة على ريثنى المصطبة) لتحسين إنتاجية القطن وذللك تحت ظروف الدراسة. 
Table (3): Effect of plant densities, N-levels and their interaction (combined data of 2011 and 2012 seasons) on some growth characters of hybrid cotton 10229 x Giza 86 under the early sowing.

\begin{tabular}{|c|c|c|c|c|c|c|c|c|c|c|c|c|c|c|}
\hline Treatments & & & & & Plant densiti & S (P) & & & Nitrog & en level & $\mathbf{s}(\mathrm{kg} / \mathrm{fec}$ & & $\mathbf{P x}$ & $\times \mathrm{N}$ \\
\hline & $\stackrel{2}{c}$ & & test & Ridges $65 \mathrm{~cm}$ & Ridges $65 \mathrm{~cm}$ & Ridges $100 \mathrm{~cm}$ & Ridges $100 \mathrm{~cm}$ & & test & & & & & \\
\hline $\begin{array}{l}\text { Growth } \\
\text { characters }\end{array}$ & 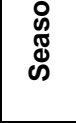 & Sig. & LSD & $\begin{array}{l}\text { width } 35 \mathrm{~cm} \\
\text { hill spacing } \\
\text { one side } \\
36923 \mathrm{pl} / \mathrm{fed} .\end{array}$ & $\begin{array}{l}\text { width } 30 \mathrm{~cm} \text { hill } \\
\text { spacing one } \\
\text { side } 43077 \\
\mathrm{pl} / \mathrm{fed} .\end{array}$ & $\begin{array}{c}\text { width } 40 \mathrm{~cm} \text { hill } \\
\text { spacing two } \\
\text { sides } 42000 \\
\text { pl/fed. }\end{array}$ & \begin{tabular}{|c} 
Width $35 \mathrm{~cm}$ hill \\
spacing two \\
sides 48000 \\
pl/fed.
\end{tabular} & Sig. & LSD & $\begin{array}{c}45 \\
\text { N/fed. }\end{array}$ & $\begin{array}{c}60 \\
\mathrm{~N} / \mathrm{fed}\end{array}$ & $\begin{array}{c}75 \\
\text { N/fed. }\end{array}$ & Sig. & LSD \\
\hline Final plant height & 2011 & $\star \star \star *$ & 2.10 & 143.33 & 145.30 & 147.10 & 149.21 & ${ }_{*}^{*}$ & 4.10 & 140.12 & 148.80 & 149.30 & NS & - \\
\hline$(\mathrm{cm})$ & 2012 & ** & 2.00 & 142.90 & 145.60 & 146.00 & 148.20 & * & 3.80 & 141.00 & 147.20 & 149.00 & NS & - \\
\hline Comb. & & $\star \star \star *$ & 2.80 & 143.12 & 145.45 & 146.55 & 148.71 & * & 3.62 & 140.56 & 148.00 & 149.15 & NS & - \\
\hline No. of monopodia & 2011 & ** & 0.70 & 1.70 & 1.90 & 2.50 & 2.70 & * & 0.82 & 1.70 & 2.00 & 2.80 & NS & 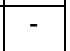 \\
\hline /plant & 2012 & ** & 1.10 & 20 & 1.70 & 2. & 2.80 & * & 0.91 & 1.30 & 2.10 & 2.70 & NS & - \\
\hline Comb. & & 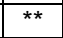 & 1.01 & 1.45 & 1.80 & 2.55 & 2.75 & * & 1.12 & 1.50 & 2.05 & 2.75 & NS & - \\
\hline No. of sympodial & 2011 & ** & 1.85 & 16.00 & 17.72 & 18.35 & 18.36 & * & 1.11 & 16.2 & 17.11 & 18.00 & NS & - \\
\hline plant & 2012 & ** & 1.10 & 17.20 & 17.55 & 18 & 10 & * & 0.88 & 17.30 & 17.80 & 18.60 & NS & - \\
\hline Comb. & & ** & 1.10 & 16.60 & 17.64 & 18.23 & 18.68 & * & 1.20 & 16.75 & \begin{tabular}{|l|}
17.46 \\
\end{tabular} & 18.30 & NS & - \\
\hline No. of main $\mathrm{s}$ & 2011 & ** & 1.80 & 21.50 & 22.75 & 23.72 & 24.80 & * & \begin{tabular}{|l|}
1.72 \\
\end{tabular} & 21.80 & 23.10 & 24.71 & NS & - \\
\hline interno & 2012 & ** & 2.10 & 20.90 & 22.81 & 23.50 & 24. & * & 1.80 & 22.00 & 23.70 & 24.70 & NS & \\
\hline Comb. & & ** & 1.90 & 21.20 & 22.78 & 23.61 & 24.88 & * & 1.35 & 21.90 & 23.40 & 24.71 & NS & - \\
\hline
\end{tabular}

${ }^{*},{ }^{* *}$ and NS indicate $P<0.05, P<0.01$ and not significant, respectively 

Table (4): Effect of plant densities, $\mathrm{N}$-levels and their interaction (combined data of 2011 and 2012 seasons) on some earliness measurements of hybrid cotton 10229 x Giza 86 under the early sowing.

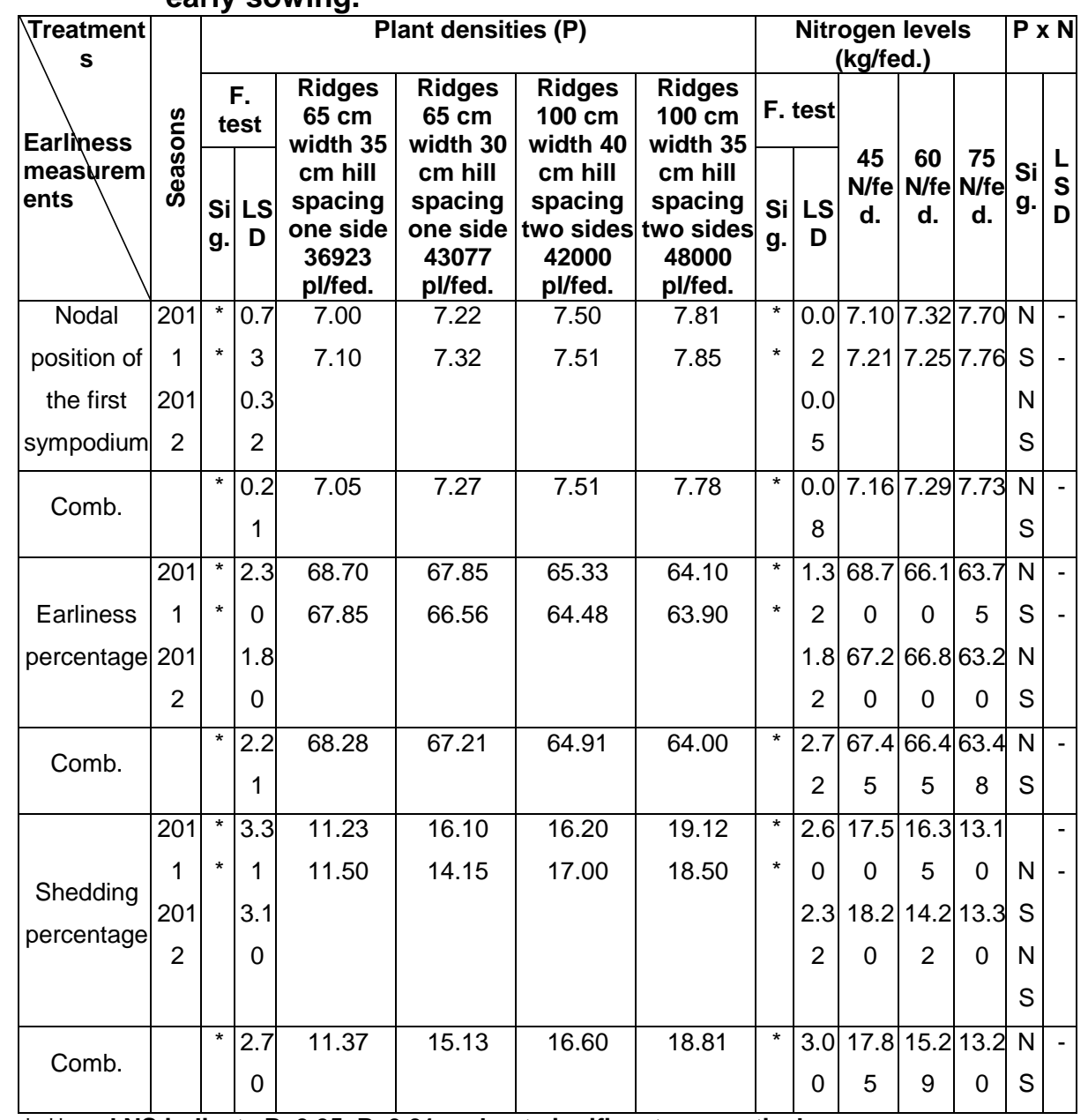

*, ** and NS indicate $P<0.05, P<0.01$ and not significant, respectively 
Table (5): Effect of plant densities, N-levels and their interaction (combined data of 2011 and 2012 seasons) on seed cotton yield and its components of hybrid cotton 10229 x Giza 86 under the early sowing.

\begin{tabular}{|c|c|c|c|c|c|c|c|c|c|c|c|}
\hline \multirow{3}{*}{$\begin{array}{l}\text { Treatments } \\
\text { Seed cotton } \\
\text { yield and } \\
\text { its components }\end{array}$} & \multirow[b]{3}{*}{ 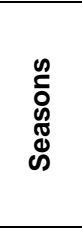 } & \multicolumn{6}{|c|}{ Plant densities (P) } & \multicolumn{4}{|c|}{ Nitrogen levels (kg/f } \\
\hline & & \multicolumn{2}{|c|}{ F. test } & \multirow[b]{2}{*}{$\begin{array}{l}\text { Ridges } 65 \mathrm{~cm} \\
\text { width } 35 \mathrm{~cm} \text { hill } \\
\text { spacing one } \\
\text { side } 36923 \\
\mathrm{pl} / \mathrm{fed} .\end{array}$} & \multirow[b]{2}{*}{$\begin{array}{c}\text { Ridges } 65 \mathrm{~cm} \\
\text { width } 30 \mathrm{~cm} \text { hil } \\
\text { spacing one } \\
\text { side } 43077 \\
\mathrm{pl} / \mathrm{fed} .\end{array}$} & \multirow[b]{2}{*}{\begin{tabular}{|c|} 
Ridges $100 \mathrm{~cm}$ \\
width $40 \mathrm{~cm}$ hill \\
spacing two \\
sides 42000 \\
pl/fed.
\end{tabular}} & \multirow[b]{2}{*}{$\begin{array}{l}\text { Ridges } 100 \mathrm{~cm} \\
\text { width } 35 \mathrm{~cm} \text { hill } \\
\text { spacing two } \\
\text { sides } 48000 \\
\mathrm{pl} / \mathrm{fed} .\end{array}$} & \multicolumn{2}{|c|}{ F. test } & \multirow[b]{2}{*}{$\begin{array}{c}45 \\
\text { N/fed. }\end{array}$} & \multirow[b]{2}{*}{$\begin{array}{c}60 \\
N / \text { fed }\end{array}$} \\
\hline & & Sig. & LSD & & & & & Sig. & LSD & & \\
\hline $\begin{array}{c}\text { No. of open } \\
\text { bolls/plant }\end{array}$ & $\begin{array}{l}2011 \\
2012\end{array}$ & * & \begin{tabular}{|l|}
0.32 \\
0.83 \\
\end{tabular} & & $\begin{array}{l}18.33 \\
15.10\end{array}$ & $\begin{array}{l}18.84 \\
15.33\end{array}$ & & * & $\begin{array}{l}0.02 \\
0.11\end{array}$ & $\begin{array}{l}18.55 \\
15.95\end{array}$ & $\begin{array}{l}18.57 \\
16.46 \\
\end{array}$ \\
\hline Comb. & & * & 0.70 & 17.30 & 16.72 & 17.10 & 17.47 & * & 0.022 & 17.25 & 17.5 \\
\hline $\begin{array}{l}\text { No. of unopen } \\
\text { bolls/plant }\end{array}$ & $\begin{array}{l}2011 \\
2012\end{array}$ & * & \begin{tabular}{|l|}
1.31 \\
1.82
\end{tabular} & $\begin{array}{l}3.65 \\
3.70\end{array}$ & $\begin{array}{l}4.10 \\
3.20\end{array}$ & $\begin{array}{l}4.72 \\
3.88\end{array}$ & $\begin{array}{l}6.35 \\
5.22\end{array}$ & * & $\begin{array}{l}1.30 \\
1.21\end{array}$ & $\begin{array}{l}3.55 \\
3.10\end{array}$ & $\begin{array}{l}4.60 \\
3.89\end{array}$ \\
\hline Comb. & & * & 1.70 & 3.68 & 3.65 & 4.30 & 5.79 & * & 1.8 & 3.33 & 4.25 \\
\hline Boll weight (g) & $\begin{array}{l}2011 \\
2012\end{array}$ & * & \begin{tabular}{|l|}
0.02 \\
0.08
\end{tabular} & $\begin{array}{l}3.17 \\
3.10\end{array}$ & $\begin{array}{l}3.20 \\
3.10\end{array}$ & $\begin{array}{l}3.24 \\
3.22\end{array}$ & $\begin{array}{l}3.25 \\
3.14\end{array}$ & * & $\begin{array}{l}0.021 \\
0.032\end{array}$ & $\begin{array}{l}3.12 \\
3.09\end{array}$ & $\begin{array}{l}3.30 \\
3.16\end{array}$ \\
\hline Comb. & & * & 0.012 & 3.20 & 3.15 & 3.32 & 3.20 & * & 0.021 & 3.11 & 3.23 \\
\hline $\begin{array}{c}\text { Seed cotton yield } \\
\text { (kentar/fed.) }\end{array}$ & $\begin{array}{l}2011 \\
2012\end{array}$ & * & \begin{tabular}{|l|}
1.32 \\
1.20 \\
\end{tabular} & $\begin{array}{l}12.83 \\
11.46\end{array}$ & $\begin{array}{l}14.67 \\
12.35\end{array}$ & $\begin{array}{l}14.10 \\
13.37\end{array}$ & $\begin{array}{l}15.65 \\
13.46\end{array}$ & * & $\begin{array}{l}0.11 \\
0.14\end{array}$ & $\begin{array}{l}13.95 \\
12.10\end{array}$ & $\begin{array}{l}14.33 \\
12.4 c\end{array}$ \\
\hline Comb. & & * & 1.32 & 12.15 & 13.51 & 13.74 & 14.56 & * & 0.21 & 13.03 & 13.38 \\
\hline Seed index & $\begin{array}{l}2011 \\
2012\end{array}$ & $\begin{array}{l}\text { NS } \\
\text { NS }\end{array}$ & $\begin{array}{l}- \\
-\end{array}$ & $\begin{array}{l}12.95 \\
13.00\end{array}$ & $\begin{array}{l}12.50 \\
12.32\end{array}$ & $\begin{array}{l}12.72 \\
12.68\end{array}$ & $\begin{array}{l}12.75 \\
12.73\end{array}$ & $\begin{array}{l}\text { NS } \\
\text { NS }\end{array}$ & $\begin{array}{l}- \\
-\end{array}$ & $\begin{array}{l}12.85 \\
12.51\end{array}$ & $\begin{array}{l}12.60 \\
12.70\end{array}$ \\
\hline Comb. & & NS & - & 12.98 & 12.41 & 12.70 & 12.74 & NS & & 12.68 & 12.65 \\
\hline Lint percentage & $\begin{array}{l}2011 \\
2012 \\
\end{array}$ & $\begin{array}{l}\text { NS } \\
\text { NS }\end{array}$ & - & $\begin{array}{l}39.21 \\
39.11 \\
\end{array}$ & $\begin{array}{l}39.02 \\
39.10 \\
\end{array}$ & $\begin{array}{l}39.20 \\
39.40 \\
\end{array}$ & $\begin{array}{l}39.55 \\
39.60 \\
\end{array}$ & \begin{tabular}{|l|} 
NS \\
NS \\
\end{tabular} & - & $\begin{array}{l}38.93 \\
38.80\end{array}$ & $\begin{array}{l}39.10 \\
39.20\end{array}$ \\
\hline Comb. & & NS & - & 39.16 & 39.06 & 39.30 & 39.58 & NS & & 38.87 & 39.15 \\
\hline $\begin{array}{c}\text { Stand losses at } \\
\text { harvest } \%\end{array}$ & $\begin{array}{l}2011 \\
2012 \\
\end{array}$ & $\begin{array}{l}\text { NS } \\
\text { NS }\end{array}$ & - & $\begin{array}{l}17.60 \\
18.70 \\
\end{array}$ & $\begin{array}{l}18.70 \\
19.00 \\
\end{array}$ & $\begin{array}{l}15.50 \\
16.20 \\
\end{array}$ & $\begin{array}{l}16.50 \\
17.30 \\
\end{array}$ & $\begin{array}{l}\text { NS } \\
\text { NS } \\
\end{array}$ & - & $\begin{array}{l}18.50 \\
18.90 \\
\end{array}$ & \begin{tabular}{|l}
17.00 \\
16.50 \\
\end{tabular} \\
\hline Comb. & & NS & - & 18.15 & 18.85 & 15.85 & 16.90 & NS & - & 18.7 & 16.75 \\
\hline
\end{tabular}

${ }^{*},{ }^{* *}$ and NS indicate $P<0.05, P<0.01$ and not significant, respectively 
Table (6): Effect of plant densities, $\mathrm{N}$-levels and their interaction (combined data of 2011 and 2012 seasons) on some fibre properties of hybrid cotton 10229 x Giza 86 under the early sowing.

\begin{tabular}{|c|c|c|c|c|c|c|c|c|c|c|c|c|c|c|}
\hline \multirow{3}{*}{$\begin{array}{l}\text { Treatments } \\
\text { pibre } \\
\text { properties }\end{array}$} & \multirow{3}{*}{ 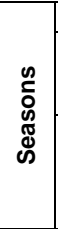 } & \multicolumn{6}{|c|}{ Plant densities (P) } & \multicolumn{5}{|c|}{ Nitrogen levels (kg/fed.) } & \multicolumn{2}{|c|}{$\mathbf{P} \times \mathbf{N}$} \\
\hline & & \multicolumn{2}{|c|}{ F. test } & \multirow{2}{*}{$\begin{array}{c}\text { Ridges } 65 \\
\text { cm width } \\
35 \mathrm{~cm} \text { hill } \\
\text { spacing } \\
\text { one side } \\
36923 \\
\text { pl/fed. }\end{array}$} & \multirow{2}{*}{$\begin{array}{c}\text { Ridges } 65 \\
\text { cm width } \\
30 \mathrm{~cm} \text { hill } \\
\text { spacing } \\
\text { one side } \\
43077 \\
\text { pl/fed. }\end{array}$} & \multirow{2}{*}{\begin{tabular}{|c|} 
Ridges 100 \\
cm width \\
$40 \mathrm{~cm}$ hill \\
spacing \\
two sides \\
42000 \\
pl/fed.
\end{tabular}} & \multirow{2}{*}{$\begin{array}{c}\text { Ridges } 100 \\
\text { cm width } \\
35 \mathrm{~cm} \text { hill } \\
\text { spacing } \\
\text { two sides } \\
48000 \\
\text { pl/fed. }\end{array}$} & \multicolumn{2}{|c|}{ F. test } & \multirow{2}{*}{$\begin{array}{c}45 \\
\mathrm{~N} / \mathrm{fed} \\
.\end{array}$} & \multirow{2}{*}{$\begin{array}{c}60 \\
\mathrm{~N} / \mathrm{fe} \\
\text { d. }\end{array}$} & \multirow{2}{*}{$\begin{array}{c}75 \\
\mathrm{~N} / \mathrm{fe} \\
\mathrm{d} .\end{array}$} & \multirow{2}{*}{$\begin{array}{l}\text { Si } \\
\text { g. }\end{array}$} & \multirow{2}{*}{$\begin{array}{c}\text { LS } \\
\text { D }\end{array}$} \\
\hline & & & $\begin{array}{c}\text { LS } \\
\text { D }\end{array}$ & & & & & & & & & & & \\
\hline $\begin{array}{c}\text { Fibre } \\
\text { fineness } \\
\text { (micronaire } \\
\text { unit) }\end{array}$ & \begin{tabular}{|c|}
201 \\
1 \\
201 \\
2 \\
\end{tabular} & $\begin{array}{l}N \\
S \\
N \\
S\end{array}$ & - & $\begin{array}{l}4.00 \\
4.00\end{array}$ & $\begin{array}{l}4.10 \\
4.09\end{array}$ & $\begin{array}{l}4.10 \\
4.10\end{array}$ & $\begin{array}{l}4.10 \\
4.00\end{array}$ & $\begin{array}{l}\text { NS } \\
\text { NS }\end{array}$ & - & $\begin{array}{l}4.0 \\
4.1\end{array}$ & \begin{tabular}{|l|}
4.10 \\
4.10
\end{tabular} & \begin{tabular}{|l|}
4.10 \\
4.00 \\
\end{tabular} & $\begin{array}{l}\mathrm{NS} \\
\mathrm{NS}\end{array}$ & $\begin{array}{l}- \\
-\end{array}$ \\
\hline Comb. & & $\begin{array}{l}\mathrm{N} \\
\mathrm{S}\end{array}$ & - & 4.00 & 4.10 & 4.10 & 4.05 & NS & - & 4.05 & 4.10 & 4.05 & NS & - \\
\hline $\begin{array}{l}\text { Fibre } \\
\text { strength } \\
\text { (g/tex) }\end{array}$ & \begin{tabular}{|c|}
201 \\
1 \\
201 \\
2 \\
\end{tabular} & $\begin{array}{l}\mathrm{N} \\
\mathrm{S} \\
\mathrm{N} \\
\mathrm{S}\end{array}$ & - & $\begin{array}{l}41.00 \\
41.00\end{array}$ & $\begin{array}{l}41.10 \\
41.00\end{array}$ & $\begin{array}{l}41.00 \\
41.10\end{array}$ & $\begin{array}{l}41.10 \\
41.00\end{array}$ & $\begin{array}{ll}\text { NS } \\
\text { NS }\end{array}$ & - & $\begin{array}{l}41.10 \\
41.00\end{array}$ & \begin{tabular}{|c|}
41.0 \\
0 \\
41.1 \\
0 \\
\end{tabular} & \begin{tabular}{|c|}
41.0 \\
0 \\
41.0 \\
0 \\
\end{tabular} & \begin{tabular}{l|}
$N S$ \\
NS
\end{tabular} & - \\
\hline Comb. & & $\begin{array}{l}\mathrm{N} \\
\mathrm{S}\end{array}$ & - & 41.00 & 41.05 & 41.05 & 41.05 & NS & - & 41.05 & \begin{tabular}{|c|}
41.0 \\
5 \\
\end{tabular} & \begin{tabular}{|c|}
41.0 \\
0
\end{tabular} & NS & - \\
\hline $\begin{array}{c}\text { Fibre length } \\
(\mathrm{mm} 2.5 \% \\
\mathrm{SL})\end{array}$ & \begin{tabular}{|c|}
201 \\
1 \\
201 \\
2 \\
\end{tabular} & $\begin{array}{l}\mathrm{N} \\
\mathrm{S} \\
\mathrm{N} \\
\mathrm{S}\end{array}$ & - & $\begin{array}{l}33.20 \\
33.40\end{array}$ & $\begin{array}{l}33.40 \\
33.30\end{array}$ & $\begin{array}{l}33.40 \\
33.40\end{array}$ & $\begin{array}{l}33.40 \\
33.30\end{array}$ & $\begin{array}{l}\text { NS } \\
\text { NS }\end{array}$ & - & $\begin{array}{l}33.30 \\
33.40\end{array}$ & \begin{tabular}{|c|}
33.4 \\
0 \\
33.3 \\
0 \\
\end{tabular} & \begin{tabular}{|c|}
33.2 \\
0 \\
33.4 \\
0 \\
\end{tabular} & $\begin{array}{l}\mathrm{NS} \\
\mathrm{NS}\end{array}$ & - \\
\hline Comb. & & $\begin{array}{l}\mathrm{N} \\
\mathrm{S}\end{array}$ & - & 33.30 & 33.35 & 33.40 & 33.35 & NS & - & 33.25 & $\begin{array}{c}33.2 \\
5 \\
\end{array}$ & \begin{tabular}{|c|}
33.3 \\
0
\end{tabular} & NS & - \\
\hline $\begin{array}{c}\text { Fibre } \\
\text { elongation \% }\end{array}$ & \begin{tabular}{|c|}
201 \\
1 \\
201 \\
2 \\
\end{tabular} & $\begin{array}{l}N \\
S \\
N \\
S\end{array}$ & $\begin{array}{l}- \\
-\end{array}$ & $\begin{array}{l}7.28 \\
7.30\end{array}$ & $\begin{array}{l}7.31 \\
7.30\end{array}$ & $\begin{array}{l}7.30 \\
7.30\end{array}$ & $\begin{array}{l}7.30 \\
7.29\end{array}$ & $\begin{array}{l}\text { NS } \\
\text { NS }\end{array}$ & - & $\begin{array}{l}7.30 \\
7.29\end{array}$ & $\begin{array}{l}7.29 \\
7.30\end{array}$ & \begin{tabular}{|l|}
7.28 \\
7.30
\end{tabular} & NS & - \\
\hline Comb. & & $\begin{array}{l}\mathrm{N} \\
\mathrm{S} \\
\end{array}$ & - & 7.30 & 7.30 & 7.30 & 7.20 & NS & - & 7.30 & 7.30 & 7.29 & NS & - \\
\hline
\end{tabular}

${ }^{*},{ }^{* *}$ and NS indicate $\mathrm{P}<0.05, \mathrm{P}<0.01$ and not significant, respectively 
Table (7): Effect of plant densities, N-levels and their interaction (combined data of 2011 and 2012 seasons) on some growth characters of hybrid cotton 10229 x Giza 86 under the late sowing.

\begin{tabular}{|c|c|c|c|c|c|c|c|c|c|c|c|c|c|c|}
\hline \multirow{3}{*}{$\begin{array}{l}\text { Treatments } \\
\text { Growth } \\
\text { characters }\end{array}$} & \multirow{3}{*}{ 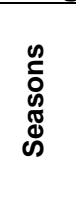 } & \multicolumn{6}{|c|}{ Plant densities (P) } & \multicolumn{5}{|c|}{ Nitrogen levels (kg/fed.) } & \multicolumn{2}{|c|}{$\mathbf{P} \times \mathbf{N}$} \\
\hline & & \multicolumn{2}{|c|}{ F. test } & \multirow{2}{*}{\begin{tabular}{|c|} 
Ridges $65 \mathrm{~cm}$ \\
width $35 \mathrm{~cm}$ hill \\
spacing one \\
side 36923 \\
pl/fed.
\end{tabular}} & \multirow{2}{*}{\begin{tabular}{|c|} 
Ridges $65 \mathrm{~cm}$ \\
width $30 \mathrm{~cm}$ hill \\
spacing one \\
side 43077 \\
pl/fed.
\end{tabular}} & \multirow[b]{2}{*}{$\begin{array}{l}\text { Ridges } 100 \mathrm{~cm} \\
\text { width } 40 \mathrm{~cm} \text { hill } \\
\text { spacing two } \\
\text { sides } 42000 \\
\text { pl/fed. }\end{array}$} & \multirow{2}{*}{\begin{tabular}{|c|} 
Ridges $100 \mathrm{~cm}$ \\
width $35 \mathrm{~cm}$ hill \\
spacing two \\
sides 48000 \\
pl/fed.
\end{tabular}} & \multicolumn{2}{|c|}{ F. test } & \multirow[b]{2}{*}{$\begin{array}{c}45 \\
N / \text { fed. }\end{array}$} & \multirow[b]{2}{*}{$\begin{array}{c}60 \\
\text { N/fed. }\end{array}$} & \multirow[b]{2}{*}{$\begin{array}{c}75 \\
\mathrm{~N} / \text { fed. }\end{array}$} & \multirow[b]{2}{*}{ Sig. } & \multirow[b]{2}{*}{ LSD } \\
\hline & & Sig. & LSD & & & & & Sig. & LSD & & & & & \\
\hline $\begin{array}{c}\text { Final plant height } \\
(\mathrm{cm})\end{array}$ & $\begin{array}{l}2011 \\
2012 \\
\end{array}$ & * & \begin{tabular}{|l|}
3.20 \\
3.31 \\
\end{tabular} & $\begin{array}{l}148.20 \\
147.72 \\
\end{array}$ & \begin{tabular}{|l|}
152.00 \\
150.12 \\
\end{tabular} & \begin{tabular}{|l|}
155.70 \\
152.00 \\
\end{tabular} & \begin{tabular}{|l|}
158.85 \\
157.95 \\
\end{tabular} & $\begin{array}{ll}\mathrm{NS} \\
\mathrm{NS} \\
\end{array}$ & - & \begin{tabular}{|l|}
145.80 \\
146.70 \\
\end{tabular} & \begin{tabular}{|l|}
156.75 \\
152.80 \\
\end{tabular} & \begin{tabular}{|l|}
158.60 \\
156.20 \\
\end{tabular} & \begin{tabular}{|l|} 
NS \\
NS \\
\end{tabular} & $\begin{array}{l}- \\
- \\
\end{array}$ \\
\hline Comb. & & * & 3.41 & 147.96 & 151.06 & 153.85 & 158.40 & NS & - & 146.25 & 154.78 & 157.40 & NS & - \\
\hline $\begin{array}{c}\text { No. of monopodia/ } \\
\text { plant }\end{array}$ & $\begin{array}{l}2011 \\
2012 \\
\end{array}$ & * & \begin{tabular}{l|}
1.20 \\
0.95 \\
\end{tabular} & $\begin{array}{l}2.90 \\
2.86 \\
\end{array}$ & $\begin{array}{l}3.10 \\
3.21 \\
\end{array}$ & $\begin{array}{l}3.56 \\
3.85 \\
\end{array}$ & $\begin{array}{l}3.89 \\
4.10 \\
\end{array}$ & $\begin{array}{l}\text { NS } \\
\text { NS }\end{array}$ & $\begin{array}{l}- \\
-\end{array}$ & \begin{tabular}{|l|}
2.95 \\
2.88 \\
\end{tabular} & \begin{tabular}{|l|}
3.50 \\
3.71 \\
\end{tabular} & \begin{tabular}{|l|}
3.75 \\
4.10 \\
\end{tabular} & $\begin{array}{l}\text { NS } \\
\text { NS } \\
\end{array}$ & - \\
\hline Comb. & & * & 0.86 & 2.88 & 3.16 & 3.71 & 3.90 & NS & - & 2.92 & 3.61 & 3.93 & NS & - \\
\hline $\begin{array}{c}\text { No. of } \\
\text { Sympodia/plant }\end{array}$ & $\begin{array}{l}2011 \\
2012 \\
\end{array}$ & * & $\begin{array}{l}1.40 \\
1.62 \\
\end{array}$ & $\begin{array}{l}13.21 \\
14.00\end{array}$ & $\begin{array}{l}14.81 \\
15.25 \\
\end{array}$ & $\begin{array}{l}15.35 \\
16.20 \\
\end{array}$ & $\begin{array}{l}16.21 \\
17.00\end{array}$ & $\begin{array}{l}\text { NS } \\
\text { NS }\end{array}$ & - & $\begin{array}{l}13.72 \\
14.40 \\
\end{array}$ & $\begin{array}{l}14.20 \\
15.67 \\
\end{array}$ & $\begin{array}{l}16.17 \\
16.82 \\
\end{array}$ & $\begin{array}{l}\text { NS } \\
\text { NS } \\
\end{array}$ & - \\
\hline Comb. & & * & 1.32 & 13.61 & 15.03 & 15.78 & 16.61 & NS & - & 14.06 & 14.94 & 16.44 & NS & - \\
\hline $\begin{array}{l}\text { No. of main stem } \\
\text { internodes/ plant }\end{array}$ & $\begin{array}{l}2011 \\
2012 \\
\end{array}$ & * & \begin{tabular}{|l|}
2.0 \\
2.12 \\
\end{tabular} & $\begin{array}{l}22.50 \\
22.35 \\
\end{array}$ & $\begin{array}{l}23.91 \\
23.00 \\
\end{array}$ & $\begin{array}{l}25.35 \\
23.95 \\
\end{array}$ & $\begin{array}{l}26.10 \\
25.70 \\
\end{array}$ & $\begin{array}{l}\text { NS } \\
\text { NS } \\
\end{array}$ & - & \begin{tabular}{|l|}
22.73 \\
22.50 \\
\end{tabular} & \begin{tabular}{|l|}
23.75 \\
23.00 \\
\end{tabular} & \begin{tabular}{|l|}
27.00 \\
25.81 \\
\end{tabular} & $\begin{array}{l}\text { NS } \\
\text { NS } \\
\end{array}$ & - \\
\hline Comb. & & * & 1.91 & 22.43 & 23.46 & 24.65 & 25.90 & NS & - & 22.62 & 23.78 & \begin{tabular}{|l|}
26.41 \\
\end{tabular} & NS & - \\
\hline
\end{tabular}

${ }^{*}$, ${ }^{*}$ and NS indicate $P<0.05, P<0.01$ and not significant, respectively 
Table (8): Effect of plant densities, N-levels and their interaction (combined data of 2011 and 2012 seasons) on some earliness measurements of hybrid cotton 10229 x Giza 86 under the late sowing.

\begin{tabular}{|c|c|c|c|c|c|c|c|c|c|c|c|c|c|c|}
\hline \multirow[b]{3}{*}{$\begin{array}{l}\text { Earliness } \\
\text { measurements }\end{array}$} & \multirow{3}{*}{ 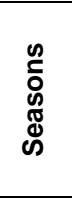 } & \multicolumn{6}{|c|}{ Plant densities (P) } & \multicolumn{5}{|c|}{ Nitrogen levels (kg/fed.) } & \multicolumn{2}{|c|}{$\mathbf{P} \times \mathbf{N}$} \\
\hline & & \multicolumn{2}{|c|}{ F. test } & \multirow{2}{*}{\begin{tabular}{|c|} 
Ridges $65 \mathrm{~cm}$ \\
width $35 \mathrm{~cm}$ hill \\
spacing one side \\
$36923 \mathrm{pl} / \mathrm{fed}$.
\end{tabular}} & \multirow{2}{*}{$\begin{array}{c}\text { Ridges } 65 \mathrm{~cm} \\
\text { width } 30 \mathrm{~cm} \text { hill } \\
\text { spacing one side } \\
43077 \mathrm{pl} / \mathrm{fed} .\end{array}$} & \multirow{2}{*}{$\begin{array}{c}\text { Ridges } 100 \mathrm{~cm} \\
\text { width } 40 \mathrm{~cm} \text { hill } \\
\text { spacing two } \\
\text { sides } 42000 \\
\text { pl/fed. }\end{array}$} & \multirow{2}{*}{$\begin{array}{c}\text { Ridges } 100 \mathrm{~cm} \\
\text { width } 35 \mathrm{~cm} \text { hill } \\
\text { spacing two } \\
\text { sides } 48000 \\
\text { pl/fed. }\end{array}$} & \multicolumn{2}{|c|}{ F. test } & \multirow{2}{*}{$\begin{array}{c}45 \\
\mathrm{~N} / \text { fed. }\end{array}$} & \multirow{2}{*}{$\begin{array}{c}60 \\
\mathrm{~N} / \mathrm{fed}\end{array}$} & \multirow{2}{*}{$\begin{array}{c}75 \\
\text { N/fed. }\end{array}$} & \multirow[t]{2}{*}{ Sig. } & \multirow[t]{2}{*}{ LSD } \\
\hline & & Sig. & LSD & & & & & Sig. & LSD & & & & & \\
\hline Nodal position of & 2011 & * & 1.10 & 7.59 & 7.81 & 8.11 & 8.81 & * & 1.10 & 7.45 & 7.82 & 8.80 & NS & \\
\hline the first sympodium & 2012 & * & 0.72 & 7.82 & 8.00 & 8.30 & 8.85 & * & 0.95 & 7.52 & 8.22 & 8.92 & NS & \\
\hline Comb. & & * & 0.85 & 7.71 & 7.91 & 8.21 & 8.83 & * & 1.20 & 7.49 & 8.02 & 8.91 & NS & \\
\hline Earliness & 2011 & * & 2.10 & 67.50 & 64.62 & 63.71 & 60.80 & * & 2.10 & 60.55 & 64.73 & 67.00 & NS & \\
\hline percentage & 2012 & * & 2.21 & 66.35 & 64.72 & 63.00 & 60.72 & * & 2.10 & 60.41 & 63.81 & 66.60 & NS & \\
\hline Comb. & & * & 2.30 & 66.93 & 64.67 & 63.36 & 60.76 & * & 2.30 & 60.48 & 64.27 & 66.80 & NS & \\
\hline Shedding & 2011 & * & 1.82 & 17.00 & 18.22 & 18.35 & 20.25 & * & 1.90 & 20.23 & 18.90 & 16.35 & NS & \\
\hline percentage & 2012 & * & 1.31 & 16.67 & 17.95 & 18.10 & 19.85 & * & 1.82 & 19.50 & 17.85 & 17.00 & NS & \\
\hline Comb. & & * & 1.52 & 16.84 & 18.09 & 18.23 & 20.05 & * & 1.95 & 19.87 & 18.38 & 16.68 & NS & \\
\hline
\end{tabular}

${ }^{*}{ }^{* \star}$ and NS indicate $\mathrm{P}<0.05, \mathrm{P}<0.01$ and not significant, respectively 
Table (9): Effect of plant densities, $\mathrm{N}$-levels and their interaction (combined data of 2011 and 2012 seasons) on seed cotton yield and its components of hybrid cotton 10229 x Giza 86 under the late sowing

\begin{tabular}{|c|c|c|c|c|c|c|c|c|c|c|c|c|c|c|}
\hline \multirow{3}{*}{$\begin{array}{l}\text { Treatments } \\
\text { Seed } \\
\text { cotton yield and } \\
\text { its components }\end{array}$} & \multirow{3}{*}{ 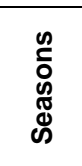 } & \multicolumn{6}{|c|}{ Plant densities ( $P$ ) } & \multicolumn{5}{|c|}{ Nitrogen levels (kg/fed.) } & \multicolumn{2}{|c|}{$S \times N$} \\
\hline & & \multicolumn{2}{|c|}{ F. test } & \multirow{2}{*}{$\begin{array}{c}\text { Ridges } 65 \mathrm{~cm} \\
\text { width } 35 \mathrm{~cm} \text { hill } \\
\text { spacing one side } \\
36923 \mathrm{pl} / \mathrm{fed} .\end{array}$} & \multirow{2}{*}{$\begin{array}{c}\text { Ridges } 65 \mathrm{~cm} \\
\text { width } 30 \mathrm{~cm} \text { hill } \\
\text { spacing one side } \\
43077 \mathrm{pl} / \mathrm{fed} .\end{array}$} & \multirow{2}{*}{$\begin{array}{l}\text { Ridges } 100 \mathrm{~cm} \\
\text { width } 35 \mathrm{~cm} \text { hill } \\
\text { spacing two sides } \\
48000 \mathrm{pl} / \mathrm{fed} .\end{array}$} & \multirow{2}{*}{\begin{tabular}{|c|} 
Ridges $100 \mathrm{~cm}$ \\
width $40 \mathrm{~cm}$ hill \\
spacing two sides \\
$42000 \mathrm{pl} / \mathrm{fed}$.
\end{tabular}} & \multicolumn{2}{|c|}{ F. test } & \multirow{2}{*}{$\begin{array}{c}45 \\
\text { N/fed. }\end{array}$} & \multirow{2}{*}{$\begin{array}{c}60 \\
\mathrm{~N} / \mathrm{fed}\end{array}$} & \multirow{2}{*}{$\begin{array}{c}75 \\
\text { N/fed. }\end{array}$} & \multirow[t]{2}{*}{ Sig. } & \multirow[t]{2}{*}{ LSD } \\
\hline & & Sig. & LSD & & & & & Sig. & LSD & & & & & \\
\hline \multirow{2}{*}{$\begin{array}{c}\text { No. of open bolls/ } \\
\text { plant }\end{array}$} & 2011 & * & 0.15 & 14.31 & 13.45 & 13.69 & 14.45 & * & 0.99 & 13.04 & 13.52 & 14.80 & NS & - \\
\hline & 2012 & * & 0.72 & 12.68 & 12.70 & 11.75 & 12.81 & * & 0.05 & 12.45 & 12.51 & 12.55 & NS & - \\
\hline Comb. & & * & 0.50 & 13.50 & 13.08 & 12.72 & 13.63 & * & 0.04 & 12.75 & 13.02 & 13.68 & NS & - \\
\hline \multirow{2}{*}{$\begin{array}{c}\text { No. of unopen } \\
\text { bolls/plant }\end{array}$} & 2011 & * & 1.2 & 3.86 & 5.22 & 4.92 & 7.85 & * & 2.1 & 3.79 & 5.10 & 7.50 & NS & - \\
\hline & 2012 & * & 2.4 & 3.10 & 4.91 & 4.20 & 6.90 & * & 1.2 & 3.82 & 4.70 & 5.80 & NS & - \\
\hline Comb. & & * & 1.3 & 3.48 & 5.07 & 4.51 & 7.38 & * & 1.4 & 3.81 & 4.90 & 6.65 & NS & - \\
\hline \multirow{2}{*}{ Boll weight (g) } & 2011 & * & 0.01 & 2.88 & 2.85 & 2.83 & 2.89 & * & 0.05 & 2.73 & 2.86 & 2.88 & NS & - \\
\hline & 2012 & * & 0.02 & 2.74 & 2.80 & 2.81 & 2.82 & * & 0.04 & 2.67 & 2.76 & 2.83 & NS & - \\
\hline Comb. & & * & $\begin{array}{ll}0.01 \\
\end{array}$ & 2.81 & 2.83 & 2.82 & 2.86 & * & & 2.70 & 2.81 & 2.86 & NS & - \\
\hline \multirow{2}{*}{$\begin{array}{l}\text { Seed cotton yield } \\
\text { (kinerar/fed.) }\end{array}$} & 2011 & * & \begin{tabular}{|l|}
0.03 \\
\end{tabular} & 10.82 & 11.02 & 11.19 & 11.34 & * & 0.80 & 10.47 & 10.82 & 11.96 & NS & - \\
\hline & 2012 & * & 1.20 & 9.70 & 11.22 & 11.33 & 11.62 & * & 0.03 & 10.43 & 11.02 & 11.47 & NS & - \\
\hline Comb. & & 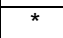 & \begin{tabular}{|l|}
0.78 \\
\end{tabular} & 10.26 & 11.12 & 11.26 & 11.48 & * & 0.70 & 10.45 & 10.92 & 11.72 & NS & - \\
\hline \multirow{2}{*}{ Seed index } & 2011 & NS & - & 12.70 & 12.73 & 12.52 & 12.84 & NS & - & 12.68 & 12.69 & 12.96 & NS & - \\
\hline & 2012 & NS & - & 12.79 & 12.69 & 12.84 & 12.91 & NS & - & 12.78 & 12.80 & 12.87 & NS & - \\
\hline Comb. & & NS & - & 12.75 & 12.71 & 12.68 & 12.88 & NS & - & 12.73 & 12.75 & 12.92 & NS & - \\
\hline \multirow{2}{*}{ Lint percentage } & 2011 & NS & - & 39.30 & 39.80 & 38.64 & 39.10 & NS & - & 39.22 & 39.30 & 39.40 & NS & - \\
\hline & 2012 & NS & - & 39.35 & 39.90 & 39.10 & 39.35 & NS & - & 39.20 & 39.35 & 39.80 & NS & - \\
\hline Comb. & & NS & - & 39.33 & 39.85 & 38.87 & 39.23 & NS & - & 39.21 & 39.33 & 39.60 & NS & - \\
\hline \multirow{3}{*}{$\begin{array}{c}\text { Stand losses at } \\
\text { harvest } \%\end{array}$} & 2011 & * & $\begin{array}{ll}0.20 \\
\end{array}$ & 14.92 & 15.30 & 15.00 & 14.42 & NS & - & 15.10 & 14.80 & 15.00 & NS & - \\
\hline & 2012 & * & 0.99 & 13.80 & 4.95 & 14.20 & 13.99 & NS & - & 14.92 & 14.75 & 13.10 & NS & - \\
\hline & & * & 0.08 & 14.36 & 15.13 & 14.60 & 14.21 & NS & - & 15.01 & 14.77 & 14.05 & NS & - \\
\hline
\end{tabular}

${ }^{\star},{ }^{\star *}$ and NS indicate $\mathrm{P}<0.05, \mathrm{P}<0.01$ and not significant, respectively 
Table (10): Effect of plant densities, $\mathrm{N}$-levels and their interaction (combined data of 2011 and 2012 seasons) on some fibre properties of hybrid cotton 10229 x Giza 86 under the late sowing.

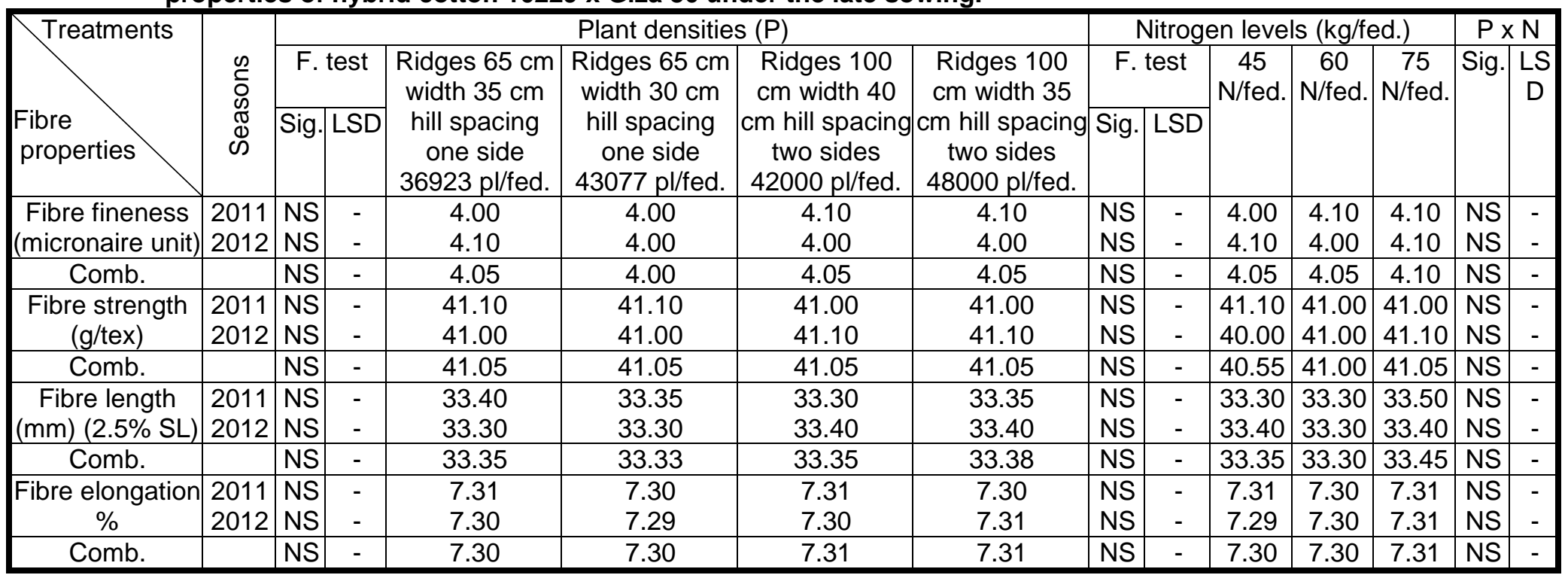

${ }^{*},{ }^{* *}$ and NS indicate $\mathrm{P}<0.05, \mathrm{P}<0.01$ and not significant, respectively 
Amal S. A. Abd El-Aal

1240

1241

1242

1243

1244

1245

1246

1247

1248

1249

1250

1251

1252

1253

1254

1255

1256

1257

1258 